九州大学学術情報リポジトリ

Kyushu University Institutional Repository

\title{
The alkyl-connected 2-amino-6-vinylpurine (AVP) crosslinking agent for improved selectivity to the cytosine base in RNA
}

Taniguchi, Yosuke

Graduate School of Pharmaceutical Sciences | CREST, Japan Science and Technology Agency

Kurose, Yusuke

Graduate School of Pharmaceutical Sciences

Nishioka, Takamasa

Graduate School of Pharmaceutical Sciences

Nagatsugi, Fumi

Institute of Multidisciplinary Research for Advanced Materials, Tohoku University | CREST, Japan Science and Technology Agency

他

ht tp://hdl. hand le. net/2324/26460

出版情報: Bioorganic and Medicinal Chemistry. 18 (8)，pp.2894-2901，2010-04-15. Elsevier バージョン：

権利関係: (C) 2010 Elsevier Ltd. 


\section{The Alkyl-Connected 2-Amino-6-Vinylprine (AVP) \\ Crosslinking Agent for Improved Selectivity to the Cytosine Base in RNA}

Yosuke Taniguchi $^{1,3}$, Yusuke Kurose ${ }^{1}$, Takamasa Nishioka ${ }^{1}$, Fumi Nagatsugi ${ }^{2,3}$, Shigeki Sasaki $^{1,3, *}$

${ }^{1}$ Graduate School of Pharmaceutical Sciences, Kyushu University, 3-1-1 Maidashi, Higashi-ku, Fukuoka 812-8582, Japan., ${ }^{2}$ Institute of Multidisciplinary Research for Advanced Materials, Tohoku University, 2-1-1 Katahira, Aoba-ku, Sendai-shi, Miyagi 98-8587, Japan and ${ }^{3}$ CREST, Japan Science and Technology Agency.

*to whom correspondence should be addressed: sasaki@phar.kyushu-u.ac.jp Tel \& FAX: +81-92-642-6651

Key Words: antisense oligonucleotide, crosslink, RNA, base selectivity 
ABSTRACT. We have previously reported that the 2-amino-6-vinylpurine (AVP) nucleoside exhibits a highly efficient and selective crosslinking reaction toward cytosine and displayed an improved antisense inhibition in cultured cells. In this study, we further investigated the alkyl-connected AVP nucleoside analogs for more efficient crosslinking to the cytosine base (rC) of the target RNA. We synthesized three AVP analogs which connect the 2-amino-6-vinylpurine unit to the 2'-deoxyribose through a methylene, an ethylene or a butylene linker. The ODN incorporating the AVP analog with the methylene or the butylene linker showed a slightly higher crosslinking to the target $\mathrm{rC}$ of RNA than the original AVP with no linker. In contrast, the AVP with the ethylene linker formed a selective and efficient crosslink to the $\mathrm{rC}$ of the target RNA. 


\section{INTRODUCTION}

RNA interactive oligonucleotides have significant potentials as therapeutic agents for the treatment of a number of diseases, such cancers, diabetes, infectious diseases, etc. ${ }^{1-7}$ Their clinical applications have attracted more and more attention since the discovery of the intrinsic and significant roles of non-coding functional RNAs in the regulation of the gene expression in living cells. Among the RNA binding molecules, the antisense oligonucleotides (ASO) have the longest research history for therapeutic applications. A variety of chemical modifications have been made on the natural-type ASO for their in vivo use, such as the phosphorothioate backbone (PS-oligonucleotide), 2'-O-methyl (2'-OMe), 2'-O-methoxyethyl (2'-MOE) and 2'-O-4'-C methylene locked nucleic acid (LNA) modified nucleotides, etc. ${ }^{8-11}$ These modifications are beneficial for the tolerance to nucleases, thermal stability of the complex with target RNAs, or penetration into cells. Another interesting strategy of ASO is the use of chemically reactive nucleotide analogs for the stabilization of the complex with the target RNA by forming a covalent bond. Psolaren photo-crosslinking units have been widely used in biological studies. We have developed the original cross-linking agent, the 2-amino-6-vinylpurine nucleoside analog (AVP), for the selective crosslinking reaction with the cytosine base (Scheme 1). Its stable precursor, the 2-amino-6-phenylthioethylpurine nucleoside (AVP (SPh)), has exhibited an improved antisense inhibition through automatic activation within the complex with the target RNA. ${ }^{12-15}$ This "induced alkylating system" has been further applied to intracellular antisense inhibition, in which the ASO containing AVP (SMe) was conjugated with PEG and formulated into nano-particles of the polyion complex micelles with poly-L-lysine. ${ }^{16}$ The AVP derivatives have other applications in the post-synthetic conjugation and in the DNA polymerase reaction. ${ }^{17-19}$ However, it was realized in subsequent studies that the reactivity of AVP depends on the target RNA sequence. It was hypothesized that the local structure of the DNA/RNA heteroduplex slightly varies with the change in the sequence and affects the closeness between the vinyl group of AVP and the amino group of the cytosine base. Thus, the new AVP derivatives were designed to have a spacer between the 2-amino-6-vinylpurine unit and 2'-deoxyribose by expecting improvement in the proximity effect to the cytosine base (Figure 1). The AVP analogs are called o-AVP with no linker 
(original), me-AVP with the methylene linker, et-AVP with the ethylene linker and bu-AVP with the butylene linker. In our earlier study, et-AVP and bu-AVP were used for the selective crosslinking to the adenine base of the TA pair, and the cytosine base of the GC pair in the triplex DNA, respectively. ${ }^{20-22}$ In this paper, we describe in detail the synthesis of the linker-containing AVP analogs, and evaluation of the crosslinking properties of the oligonucleotides incorporating them.

\section{RESULT}

\subsection{Synthesis}

\section{Synthesis of the methylene-linked 2-amino-6-vinylpurine derivative (me-AVP-SMe).}

The synthesis of the new nucleoside analogue, the methylene linked 2-amino-6-vinylpurine derivative 4, is shown in Scheme 2. 1'- $\beta$-Cyano-2'-deoxyribose $\mathbf{1}^{24}$ was converted to the tosylated sugar unit $2^{23}$ in $66 \%$ yield by a sequence of reactions including hydrolysis, reduction of the resulting carboxylic acid using borate, and subsequent treatment with tosylchrolide. The displacement of the tosylate group of 2 with 6-chloro-2-aminopurine afforded the $7 \mathrm{~N}$-alkylated product as the major product in $68 \%$ after purification by silica-gel column chromatography $(7 \mathrm{~N} /$ 9N > 49:1). The Pd(II)-catalyzed cross-coupling reaction with the 2,4,6-trivinylcyclotriboroxane pyridine complex ${ }^{25}$ gave the 2-amino-6-vinylpurine (AVP) derivative, which afforded 3 by the reaction with NaSMe. After removal of the toluoyl protecting groups, the corresponding diol groups were transiently protected with TMS groups ${ }^{26}$, followed by protection of the 2 -amino 
group with phenoxyacetyl chloride to produce 4 (me-AVP-SMe) in $68 \%$ yield from 3 in two steps.

The synthesis of et-AVP-SMe and bu-AVP-SMe was performed as previously reported. ${ }^{21,22}$ The abbreviation -SMe represents the fact that the vinyl group of AVP is protected by the methylsulfide group.

\section{Synthesis of the amidite precursor and the oligonucleotide containing the AVP derivative.}

As shown in Scheme 3, the diol compounds 4 (o-, me-, et- and bu-AVP-SMe) were converted to the corresponding phosphoroamidite precursors $\mathbf{5}$ by the conventional method. The phosphoramidite precursors (5) were incorporated into ODNs using the DNA automated synthesizer. The synthesized ODNs 6 were purified by HPLC, the DMTr protecting group was removed in an aqueous $\mathrm{AcOH}$ solution, and their structures were identified by MALDI-TOF MS measurements. These results are summarized in Table 1. The purified ODNs were treated with magnesium monoperoxyphthalate (MMPP) followed by treatment with an aqueous $\mathrm{NaOH}$ solution to generate the vinyl group of ODNs 7, which were purified by HPLC again, and confirmed by a MALDI-TOF MS measurement (data not shown).

\subsection{Estimation of crosslinking reactions with oligonucleotides containing AVP derivatives}

\section{for DNA or RNA}

The crosslinking reactions of 16 mer ODNs, o-ODN(8), me-ODN(8), et-ODN(8) and bu-ODN(8) containing AVP were performed using the FAM-labeled complementary DNA and RNA, and its 
progress was followed by the denatured gel mobility shift assay including $7 \mathrm{M}$ urea. The yield of the crosslinked products were determined by quantification of the fluorescent bands based on the bands corresponding to the non-reacted target DNA and RNA Examples of the gel results of the o-ODN(8)/RNA and et-ODN(8)/RNA heteroduplex are shown in Figure 2. The time-dependent changes in the obtained alkylation yields are summarized in Figure 3. Previously, we reported that ODN having the original structure of AVP, $\mathbf{o - O D N}(\mathbf{8})$, exhibited a highly efficient and selective crosslinking reaction toward $\mathrm{dC}$ in the complimentary DNA (Figure 3A). However, almost no crosslinking ability by $\mathbf{0 - O D N}(\mathbf{8})$ was observed for any base in the target RNA (Figure 2A, 3E). As the reactivity of the vinyl group of AVP is highly dependent on the distance to the amino group, these results indicate that the proximity effect between AVP and rC is lost in the DNA/RNA hetero duplex of this sequence. The ODN me-ODN(8) with AVP connected by the methyl linker showed less reactivity and specificity in the crosslinking reaction with the DNA targets, and displayed only a negligible reactivity to the RNA targets (Figure 3B and 3F). In a remarkable contrast, et-ODN(8) including AVP connected by the ethyl linker exhibited a high crosslinking reactivity with a high selectivity to $\mathrm{rC}$ in DNA/RNA hetero duplex (Figure $2 \mathrm{~B}$ and $3 \mathrm{G}$ ), although a lower reactivity and selectivity were observed to the DNA targets (Figure 3C). The ODN bu-ODN(8) did not show any significant crosslinking reactivity either to the DNA or the RNA targets (Figure $3 \mathrm{D}$ and $3 \mathrm{H})$. These results clearly indicated that the optimal length of the spacer between the AVP 
unit and the 2'-deoxyribose group is the ethylene linker for the rC of DNA/RNA sequences used in this study.

As RNA generally forms a secondary structure under physiological conditions, we tested the crosslinking ability of the alkyl-linked AVP structure to the 27 mer RNA target with a hairpin-loop structure using o-ODN(9) and et-ODN(9), which have the AVP unit at the complementary site toward the $\mathrm{rC}$ in the loop position of the RNA target (Figure 4A). As predicted from the results of Figure 3E, o-ODN(9) did not show a high reactivity to this loop RNA target (Figure 4B). On the other hand, et-ODN(9) displayed a selective crosslinking ability to $\mathrm{rC}$, although the alkylating yield for the loop RNA is slightly lower than that with the linear RNA (Figure 4C).

To further check the sequence dependency, the 27 mer FAM-labeled RNAs (FAM-RNA15 and 16) were designed as the model sequence of the luciferase mRNA. The time course of the crosslinking yields between FAM-RNA15 with o-, et-ODN(10) is shown in Figure 5A, and those between FAM-RNA16 and o-, et-ODN(11) are summarized in Figure 5B. Unexpected findings were that crosslinked products were formed in the reaction of FAM-RNA15 having rU at the target site with o-ODN(10) and et-ODN(10), although the highest yields were obtained with et-ODN(10) toward $\mathrm{rC}$ at the target site of FAM-RNA15 (Figure 5A). The structure determination of the adduct with $\mathrm{rU}$ is needed for discussion of this unexpected crosslinking, but an alkylation with the carbonyl group of rU might be included like a new crosslinking agent for $\mathrm{rU}^{27}$ On the 
other hand, the results with the FAM-RNA16 were consistent with the prediction of a low reactivity with o-ODN(11) and $\mathrm{rC}$ selectivity with et-ODN(11) (Figure 5B). These results have clearly suggested that the sequence dependency of the original AVP analog has been overcome with the ethylene-linked AVP analog, but nevertheless, there is the still need to design a suitable RNA sequence for the target site of crosslinking.

\subsection{The thermal stability and conformation of the DNA/RNA duplexes formed with the}

\section{ODN containing the AVP analog.}

It may be assumed that the sequence dependency regarding the reactivity and the selectivity may arise from the thermal stability and the conformation of the duplexes. The thermal stability was estimated by measuring the melting temperature $\left(T_{m}\right)$ of the duplex formed between the 21 mer ODN containing the AVP, ODN(10 or 11) with the 27 mer RNA, RNA15 or RNA16 (Figure 6A and 6B), and the results are summarized in Table 2. The $T_{m}$ value of the RNA15/o-ODN(10) duplex was slightly lower than that of the RNA15/et-ODN(10) duplex, and both were lower than that of the ODN(10)/RNA15 duplex $\left(55.8^{\circ} \mathrm{C}\right)$. In the case of the duplex with RNA16, the $T_{m}$ value with o-, et-ODN(11) was more than $10^{\circ} \mathrm{C}$ lower than that with the natural ODN(11) containing dG instead of the AVP derivative. These results indicate that the duplex is destabilized by the alkylating structure regardless of the presence or absence of the alkyl linker. The RNA16/et-ODN(11) duplex produced a crosslinked product with a high rC selectivity, but gave 
only low $T_{m}$ values. Accordingly, it was shown that the thermal stability of the duplex is not the major contributor of the crosslinking reactivity.

The circular dichroism spectra were measured to check the conformational change in the ODN/RNA heteroduplex. The CD spectra of the duplex formed with RNA15 and ODN(10), o-ODN(10) and et-ODN(10) are compared in Figure 6C, and those formed with RNA16 and ODN(11), o-ODN(11) and et-ODN(11) are shown in Figure 6D. All of these CD spectra indicate that the heteroduplexes are in between the A- and B-conformation and are similar to each other, suggesting that a large conformational change is not responsible for the difference in the crosslinking reactivity.

\section{DISCUSSION}

This study aimed to develop an efficient crosslinking agent based on the 2-amino-6-vinylpurine (AVP) unit in order to crosslink with the RNA molecules. The AVP analogues were designed to connect the 2-amino-6-vinylpurine to the 2'-deoxyribose via a linker with a different length to optimize the linker length for better crosslinking efficiency.

Among the three linkers, the methylene, ethylene and butylene linker, the best improvement in the crosslinking reactivity as well as the selectivity to $\mathrm{rC}$ was obtained with the ethylene linker analogue, et-AVP. To the RNA targets where the original AVP did not produce a significant 
crosslinked product, et-AVP produced the crosslinked products in high yield with a high $\mathrm{rC}$ selectivity. The sequence-dependency of the reactivity of the original AVP to rC in RNA has been overcome by et-AVP, although some limitations still remain. The high reactivity of et-AVP toward $\mathrm{rC}$ in RNA compared to the original AVP cannot be explained either by the difference in the thermal stability or the difference in the duplex conformation. Generally, the geometries of the GC and AT base pairs are almost same in the DNA/DNA duplex and the DNA/RNA heteroduplex. However, it is apparent that a slight difference in the geometry of AVP to the rC complex significantly affected the alkylating ability of the AVP analogs. The thermal denaturing study and the $\mathrm{CD}$ results have shown that the DNA/RNA heteroduplex is between the A- and B-type conformation with only a slight distortion because of o-AVP-SMe and et-AVP-SMe. It has been proposed by MD calculation that base pairs in duplex RNA experience local opening events into the major groove, while such events are not simulated in the DNA duplex. ${ }^{28}$ In the DNA/RNA heteroduplex in the conformation between A and B-type, the 2-amino-6-vinylpurine base may cause such a conformational change to open the AVP-cytosine mismatch base pair and push the cytosine base into the major groove (Figure 7, A1 vs A2). In such a conformation, the amino group of the cytosine base is no longer in close proximity with the vinyl group of the original AVP without the linker. On the other hand, the ethylene-linked 2-amino-6-vinylpurine base (et-AVP) might reach the cytosine base in a distorted conformation (Figure 7, B1 vs B2). Although there is 
no experimental evidence, it may be speculated that the ethylene linker makes the 2-amino-6-vinyl

purine unit flexible in order to adjust the movement of the cytosine base. In conclusion, it has been clearly shown that the nucleoside analog, et-AVP, having the 2-amino-6-vinylpurine unit through the ethylene linker is an efficient and selective crosslinking agent to the $\mathrm{rC}$ in the RNA target.

\section{MATERIALS AND METHODS}

\subsection{General}

All reactions were performed under an argon atmosphere. The ${ }^{1} \mathrm{H}$ NMR (400 and $500 \mathrm{MHz}$ ) spectra were recorded by a Varian UNITY-400 and INOVA-500 spectrometer, respectively. The

${ }^{31} \mathrm{P}$ NMR $(161 \mathrm{MHz})$ spectrum was recorded using $10 \%$ phosphoric acid in $\mathrm{D}_{2} \mathrm{O}$ for the internal standard at $0 \mathrm{ppm}$. The IR spectra were obtained using a Perkin Elmer FTIR-SpectrumOne. The high-resolution mass spectra were recorded by an Applied Biosystems Mariner System 5299 spectrometer. The MALDI-TOF mass spectra were recorded by a Bruker Daltonics Microflex instrument.

\subsubsection{2-Deoxy-1-tosyloxymethyl-3,5-O-ditoluoyl- $\beta$-D-ribofuranose (2)}

A solution of 1 (814 mg, $2.15 \mathrm{mmol}), 1,4$-dioxane $(20 \mathrm{ml})$ and a $36 \%$ aqueous $\mathrm{HCl}$ solution (1.87 ml) was refluxed at $80^{\circ} \mathrm{C}$ for $2 \mathrm{hr}$. The reaction mixture was quenched with a sat. $\mathrm{NaHCO}_{3}$ solution and extracted with $\mathrm{CHCl}_{3}$. The organic layer was dried over $\mathrm{Na}_{2} \mathrm{SO}_{4}$, and evaporated. 
The residue was dissolved in THF and cooled to $0^{\circ} \mathrm{C}$. The $\mathrm{BH}_{3}-\mathrm{THF}$ complex $(9.7 \mathrm{ml}, 9.65 \mathrm{mmol})$ was slowly added to this solution at $0^{\circ} \mathrm{C}$. After stirring for $1.5 \mathrm{hr}$ at room temperature, the reaction mixture was quenched with a $10 \%$ aqueous $\mathrm{HCl}$ solution and extracted with $\mathrm{CHCl}_{3}$. The organic layer was dried over $\mathrm{Na}_{2} \mathrm{SO}_{4}$, and then evaporated. The residue was purified by silica-gel column chromatography (hexane/EtOAc $=1: 1)$ to give a colorless oil $(680 \mathrm{mg}, 1.72 \mathrm{mmol}, 80 \%$ for two steps). $p$-Toluenesulfonyl chloride ( $p$-TsCl) $(476 \mathrm{mg}, 2.5 \mathrm{mmol})$ was added to a solution of the colorless oil $(600 \mathrm{mg}, 1.56 \mathrm{mmol})$ in pyridine $(6.0 \mathrm{ml})$ at $0^{\circ} \mathrm{C}$. After stirring for $24 \mathrm{hr}$, the reaction mixture was poured into ice water and extracted with $\mathrm{CHCl}_{3}$. The organic layer was dried over $\mathrm{Na}_{2} \mathrm{SO}_{4}$, and evaporated. The residue was purified by silica-gel column chromatography (hexane/EtOAc $=1: 1)$ to give 2 as a pale yellow oil $(693 \mathrm{mg}, 1.29 \mathrm{mmol}, 83 \%) .{ }^{1} \mathrm{H}$ NMR $(400$ $\left.\mathrm{MHz}, \mathrm{CDCl}_{3}\right): \delta 7.92-7.87(4 \mathrm{H}, \mathrm{m}), 7.77-7.75(2 \mathrm{H}, \mathrm{m}), 7.28-7.22(6 \mathrm{H}, \mathrm{m}), 5.44(1 \mathrm{H}, \mathrm{d}, J=4.0$ Hz), 4.48-4.30 (2H, m), 4.21-4.09 (2H, m), $2.41(3 \mathrm{H}, \mathrm{s}), 2.40(3 \mathrm{H}, \mathrm{s}), 2.35(3 \mathrm{H}, \mathrm{s}), 2.24-2.12(2 \mathrm{H}$, m). FTIR (neat): 1718, $1270 \mathrm{~cm}^{-1}$. ESI-MS: $539.08(\mathrm{M}+\mathrm{H})^{+}$.

\subsubsection{2-Amino-9-[2-(2'-deoxy- $\beta$-D-ribofuranosyl)methyl]-6-(2-methylthioethyl)purine (3)}

2-Amino-6-chloropurine (432 mg, $2.55 \mathrm{mmol}$ ) was added to a solution of potassium $t$-butoxide (301 mg, $2.55 \mathrm{mmol}$ ) in dimethylsulfoxide (DMSO) (5.0 ml). After stirring for $1.5 \mathrm{hr}$, a solution of $2(686 \mathrm{mg}, 1.27 \mathrm{mmol})$ in DMSO $(5.0 \mathrm{ml})$ was added to the above mixture, then the reaction mixture was refluxed for $3 \mathrm{hr}$ at $80^{\circ} \mathrm{C}$. The reaction mixture was quenched with sat. ammonium 
chloride solution and extracted with EtOAc. The organic layer was successively washed with water and brine, dried over $\mathrm{Na}_{2} \mathrm{SO}_{4}$, and evaporated. The residue was purified by silica-gel column chromatography (hexane/EtOAc $=1: 1)$ to give a colorless oil $(357 \mathrm{mg}, 0.67 \mathrm{mmol}, 52 \%)$. Tetrakis(triphenylphosphine)palladium(0) (70.5 mg, $0.061 \mathrm{mmol})$, lithium bromide (64.9 mg, 0.73 $\mathrm{mmol})$, potassium bicarbonate $(50.8 \mathrm{mg}, 0.37 \mathrm{mmol})$ and 2,4,6-trivinylcyclotriboroxane pyridine complex (212 mg, $0.85 \mathrm{mmol})$ were added to a solution of the colorless oil ( $327 \mathrm{mg}, 0.61 \mathrm{mmol})$ in water $/$ dioxane $=1: 3(11.5 \mathrm{ml})$. The reaction mixture was refluxed for $1 \mathrm{hr}$ at $120^{\circ} \mathrm{C}$, and quenched with a sat. ammonium chloride solution and extracted with EtOAc. The organic layer was successively washed with water and brine, dried over $\mathrm{Na}_{2} \mathrm{SO}_{4}$, and evaporated to give a brown caramel $(506 \mathrm{mg})$. This brown caramel solution in acetonitrile $(5.0 \mathrm{ml})$ was treated with sodium methanethiolate solution $(0.43 \mathrm{ml}, 0.92 \mathrm{mmol})$ for $15 \mathrm{~min}$. The reaction mixture was diluted with $\mathrm{CHCl}_{3}$. The organic layer was continuously washed with water and brine, dried over $\mathrm{Na}_{2} \mathrm{SO}_{4}$, and evaporated. The residue was purified by silica-gel column chromatography (hexane/EtOAc $=1: 2$ to $1: 1$ to EtOAc only) to give 3 as a yellow caramel (330 mg, $0.57 \mathrm{mmol}, 94 \%) .{ }^{1} \mathrm{H}$ NMR (400 $\left.\mathrm{MHz}, \mathrm{CDCl}_{3}\right): \delta 7.90-7.83(4 \mathrm{H}, \mathrm{m}), 7.85(1 \mathrm{H}, \mathrm{s}), 7.25-7.20(4 \mathrm{H}, \mathrm{m}), 5.46(1 \mathrm{H}, \mathrm{d}, J=6.1 \mathrm{~Hz}), 5.18$ (2H, bs), 4.56-4.52 (2H, m), 4.45-4.36 (2H, m), 3.33-3.19 (1H, m), 3.02-3.00 (1H, m), $2.41(3 \mathrm{H}$, s), $2.40(3 \mathrm{H}, \mathrm{s}), 2.38-2.29(1 \mathrm{H}, \mathrm{m}), 2.17(3 \mathrm{H}, \mathrm{s}), 2.13-1.96(1 \mathrm{H}, \mathrm{m})$. FTIR (neat): $1716,1610 \mathrm{~cm}^{-1}$. ESI-MS: $570.20(\mathrm{M}+\mathrm{H})^{+}$. 


\subsubsection{9-[2-(2'-deoxy- $\beta$-D-ribofuranosyl)methyl]-6-(2-methylthioethyl)-2-phenoxyacetyl-}

\section{aminopurine (4)}

Sodium methoxide (153 mg, $2.7 \mathrm{mmol})$ was added to a solution of $3(155 \mathrm{mg}, 0.27 \mathrm{mmol})$ in $\mathrm{MeOH}(7.0 \mathrm{ml})$, then the reaction mixture was refluxed at $70^{\circ} \mathrm{C}$ for $1 \mathrm{hr}$. The reaction mixture was quenched with a sat. ammonium chloride solution and extracted with EtOAc. The organic layer was continuously washed with water and brine, dried over $\mathrm{Na}_{2} \mathrm{SO}_{4}$, and evaporated. The residue was dissolved in pyridine/ $\mathrm{CH}_{2} \mathrm{Cl}_{2}=1: 3(6.4 \mathrm{ml})$ and cooled to $0^{\circ} \mathrm{C}$ in an ice bath. Trimethylsilyl chloride $(0.34 \mathrm{ml}, 2.69 \mathrm{mmol})$ was added to this mixture. After stirring for $1.5 \mathrm{hr}$ at room temperature, the mixture was cooled to $0^{\circ} \mathrm{C}$ again. Penoxyacetyl chloride $(37 \mu 1,0.39 \mathrm{mmol})$ was added to this mixture at $0^{\circ} \mathrm{C}$. The reaction mixture was stirred for $3 \mathrm{hr}$ at the same temperature, and diluted with $\mathrm{CH}_{3} \mathrm{OH}(1.6 \mathrm{ml})$. After stirring for $12 \mathrm{hr}$ at room temperature, the reaction mixture was diluted with $\mathrm{CHCl}_{3}$. The organic layer was washed with water, dried over $\mathrm{Na}_{2} \mathrm{SO}_{4}$, and evaporated. The residue was purified by silica-gel column chromatography $\left(\mathrm{CHCl}_{3} / \mathrm{CH}_{3} \mathrm{OH}=\right.$ 10:1) to give 4 as a colorless caramel ( $86.4 \mathrm{mg}, 0.18 \mathrm{mmol}, 68 \%$ for two steps). ${ }^{1} \mathrm{H}$ NMR (400 $\left.\mathrm{MHz}, \mathrm{CDCl}_{3}\right): \delta 9.10(1 \mathrm{H}, \mathrm{s}), 8.09(1 \mathrm{H}, \mathrm{s}), 7.34-7.30(2 \mathrm{H}, \mathrm{m}), 7.05-7.00(3 \mathrm{H}, \mathrm{m}), 6.83(1 \mathrm{H}, \mathrm{d}, J=$ $6.3 \mathrm{~Hz}), 4.78-4.74(2 \mathrm{H}, \mathrm{m}), 4.54-4.50(1 \mathrm{H}, \mathrm{m}), 4.44-4.39(2 \mathrm{H}, \mathrm{m}), 4.30-4.27(1 \mathrm{H}, \mathrm{m}), 3.85(1 \mathrm{H}, \mathrm{d}$, $J=3.4 \mathrm{~Hz}), 3.64-3.55(2 \mathrm{H}, \mathrm{m}), 3.43-3.39(2 \mathrm{H}, \mathrm{m}), 3.07-3.03(2 \mathrm{H}, \mathrm{m}), 2.16(3 \mathrm{H}, \mathrm{s}), 2.13-2.09(1 \mathrm{H}$, m), 1.96-1.92 (1H, m). FTIR (neat): 3379, 2918, 1691, $1600 \mathrm{~cm}^{-1}$. ESI-MS: $474.24(\mathrm{M}+\mathrm{H})^{+}$. 


\subsection{4.}

9-[2-(2'-deoxy-3'-O-N,N-diisopropylcyanoethylphosphoramidyl-5'-O-(4,4'-dimethoxytrityl)

\section{$\beta$-D-ribofuranosyl)methyl]-6-(2-methylthioethyl)-2-phenoxyacetylaminopurine (5)}

$\operatorname{DMTrCl}(92 \mathrm{mg}, 0.26 \mathrm{mmol})$ was added to a solution of 4 (96 mg, $0.2 \mathrm{mmol})$ in pyridine containing molecular sieves 4A. After stirring for $1 \mathrm{hr}$, the reaction mixture was diluted with $\mathrm{CHCl}_{3}$, and then washed with water and brine. The organic layer was washed with water and brine, dried over $\mathrm{Na}_{2} \mathrm{SO}_{4}$, evaporated, and then the residue was purified by silica-gel column chromatography $\left(\mathrm{CHCl}_{3}\right.$ containing $0.5 \%$ pyridine $)$ to give the DMTr-protected compound (96.1 $\mathrm{mg}, 0.12 \mathrm{mmol}, 61 \%)$. Subsequently, $i \mathrm{P}_{2} \mathrm{NEt}(67 \mu 1,0.39 \mathrm{mmol})$ was added to this solution of the DMTr-compound (50 mg, $0.06 \mathrm{mmol})$ and $i \mathrm{Pr}_{2} \mathrm{NP}(\mathrm{Cl}) \mathrm{OC}_{2} \mathrm{H}_{4} \mathrm{CN}(43 \mu \mathrm{l}, 0.19 \mathrm{mmol})$ in $\mathrm{CH}_{2} \mathrm{Cl}_{2}$ at $0^{\circ} \mathrm{C}$. After stirring for $30 \mathrm{~min}$, the reaction mixture was diluted with a sat. $\mathrm{NaHCO}_{3}$ solution, and extracted with EtOAc. The organic layer was dried over $\mathrm{Na}_{2} \mathrm{SO}_{4}$, evaporated, and then the residue was purified by flash silica-gel column chromatography (hexane/EtOAc $=2: 1$ ) to give $\mathbf{5}$ as a white powder (39 mg, $0.04 \mathrm{mmol}, 62 \%) .{ }^{1} \mathrm{H} \mathrm{NMR}\left(400 \mathrm{MHz}, \mathrm{CDCl}_{3}\right): \delta 8.88(1 \mathrm{H}, \mathrm{bs}), 8.12(1 \mathrm{H}, \mathrm{s})$, 7.43-7.28 (10H, m), 7.23-7.19 (2H, m), 7.06-7.01 (3H, m), $6.83(4 \mathrm{H}, \mathrm{dd}, J=7.0,1.5 \mathrm{~Hz})$, 4.80-4.78 (2H, m), 4.59-4.39 (3H, m), 4.19-4.11 (3H, m), $3.79(3 \mathrm{H}, \mathrm{s}), 3.78(3 \mathrm{H}, \mathrm{s}), 3.74-3.68$ $(1 \mathrm{H}, \mathrm{m}), 3.66-3.57(1 \mathrm{H}, \mathrm{m}), 3.54-3.48(2 \mathrm{H}, \mathrm{m}), 3.46-3.39(2 \mathrm{H}, \mathrm{m}), 3.16-3.15(2 \mathrm{H}, \mathrm{m}), 3.07(2 \mathrm{H}$, $\mathrm{t}, J=7.63 \mathrm{~Hz}), 2.75(1 \mathrm{H}, \mathrm{t}, J=6.41 \mathrm{~Hz}), 2.40(1 \mathrm{H}, \mathrm{t}, J=6.41 \mathrm{~Hz}), 2.18(3 \mathrm{H}, \mathrm{s}), 1.14(6 \mathrm{H}, \mathrm{d}, J=$ 
$6.72 \mathrm{~Hz}), 1.10(6 \mathrm{H}, \mathrm{d}, J=6.72 \mathrm{~Hz})$. FTIR (neat): 2967, 2364, 1697, $1600 \mathrm{~cm}^{-1}$. ESI-MS: 976.71

$(\mathrm{M}+\mathrm{H})^{+} .{ }^{31} \mathrm{P}$ NMR $\left(161 \mathrm{MHz}, \mathrm{CDCl}_{3}\right): \delta 148.7,148.5$.

\subsection{Oligonucleotides (6).}

The 2'-deoxy oligonucleotides (ODNs) containing the AVP derivative were synthesized using an automated DNA synthesizer (Applied Biosystems 394 DNA/RNA synthesizer) on a $1.0 \mu \mathrm{mol}$ scale. The synthesized ODNs were cleaved from CPG by $28 \%$ aqueous ammonium hydroxide at room temperature and purified by HPLC (conditions: column, Nacalai Tesque COSMOSIL 5C18AR-II $10 \times 250 \mathrm{~mm}$; flow rate, $3.0 \mathrm{ml} / \mathrm{min}$; buffer A, $0.1 \mathrm{M}$ TEAA; B, $\mathrm{CH}_{3} \mathrm{CN}$; B concentration $10 \%$ to $40 \% / 20 \mathrm{~min}, 40 \%$ to $100 \% / 30$ min, linear gradient). The DMTr-protecting groups of the purified ODNs were removed by $10 \%$ acetic acid and the formed DMTrOH was extracted with $\mathrm{Et}_{2} \mathrm{O}$. The structure of the synthetic ODNs was confirmed by a MALDI-TOF MS measurement. The MALDI-TOF MS results are summarized in Table 1.

\subsection{The crosslinking reaction and the analysis by denatured polyacylamide gel.}

The methylthio group of ODN in the oligonucleotides 6 was converted to the vinyl group 7 by MMPP (2.0 equiv.) and aqueous sodium hydroxide at room temperature. The RNase OUT (40 unit), reaction buffer (final conc.; $100 \mathrm{mM} \mathrm{NaCl}$ and $50 \mathrm{mM} \mathrm{MES,} \mathrm{pH5)} \mathrm{and} \mathrm{FAM-labeled} \mathrm{target}$ DNA or RNA (50 pmol) were added to the above mixture at $0^{\circ} \mathrm{C}$. The reaction mixture was incubated at $37^{\circ} \mathrm{C}$, and the reaction was stopped by mixing with a buffer (95\% formamide, $20 \%$ 
EDTA, $0.05 \%$ bromophenol blue) at the appropriate time. The reaction progress was analyzed by electrophoresis with $15 \%$ denatured polyacrylamide gel containing $7 \mathrm{M}$ urea, and the intensity of

FAM-labeled bands were quantified by a luminescent image analyzer LAS-3000 (Fujifilm).

\subsection{Thermal denaturing study ( $T_{m}$ value).}

A mixture of the corresponding ODN $6(1.5 \mu \mathrm{M})$ and 27 mer of the complimentary RNA $(1.5 \mu \mathrm{M})$

in the buffer $(100 \mathrm{mM} \mathrm{NaCl}$ and $50 \mathrm{mM} \mathrm{MES}, \mathrm{pH} 5)$ was heated at $85^{\circ} \mathrm{C}$ for $10 \mathrm{~min}$ then slowly cooled. The melting curve was obtained by warming a sample at the rate of $1.0^{\circ} \mathrm{C} / \mathrm{min}$ from 20 to $80{ }^{\circ} \mathrm{C}$ with monitoring at $260 \mathrm{~nm}$ by a UV-Vis spectrophotometer, DU 800 (Beckman Coulter).. The data were analyzed by the melt curve processing program, MeltWin v. 3.5.

\subsection{Circular dichroism (CD) spectroscopy}

The CD spectra were measured by a JASCO J-720W spectrophotometer at room temperature in a cylindrical quartz cell with a path length of $0.1 \mathrm{~cm}$. The samples were prepared in the same manner as described in the thermal denaturing study. The Spectra were converted to a molar ellipticity, which was performed by the JASCO standard analysis software.

\section{ACKNOWLEDGEMENT}

This work was supported by a Grant-in-Aid for Scientific Research (S) from the Japan Society for Promotion of Science, and CREST from the Japan Science and Technology Agency.

\section{REFERENCES}

1. Matsubara, H.; Takeuchi, T.; Nishikawa, E.; Yanagisawa, K.; Hayashita, Y.; Ebi, H.; Yamada, 
H.; Suzuki, M.; Nagino, M.; Nimura, Y.; Osada, H.; Takahashi, T. Oncogene, 2006, 26, 6099.

2. Stenvang, J.; Lindow, M.; Kauppinen, K. Biochem. Soc. Trans., 2008, 36, 1197.

3. Horwich, M. D.; Zamore, P. D. Nat. Protoc., 2008, 3, 1537.

4. Fei, J. L.; Feiei, G.; Ming, Li. Y.; Liu, Y. J. Drug Target., 2008, 16, 688.

5. Yu, R. Z.; Lemonidis, K. M.; Graham, M. J.; Matson, J. E.; Crooke, R. M.; Tribble, D. L.; Wedel, M. K.; Levin, A. A.; Geary, R. S. Biochem. Pharmacol., 2009, 77, 910-919.

6. Crooke, S. T. CRC Press, 2007, Boca Raton.

7. Aboul-Fadl, T. Expert Opin. Drug Discov., 2006, 1, 285.

8. Elmén1, J.; Lindow, M.; Schütz, S.; Lawrence, M.; Petri, A.; Obad, S.; Lindholm, M.; Hedtjärn, M.; Hansen, H. F.; Berger, U.; Gullans, S.; Kearney, P.; Sarnow, P.; Straarup, E. M.; Kauppinen, S. Nature, 2008, 452, 896.

9. Elmén, J.; Lindow, M.; Silahtaroglu, A.; Bak, M.; Christensen, M.; Lind-Thomsen, A.; Hedtjärn, M.; Hansen, J. B.; Hansen, H. F.; Straarup, E. M.: McCullagh, K.; Kearney, P.; Kauppinen, S. Nucleic Acids Res., 2008, 36, 1153.

10. Tillman, L. G.; Geary, R. S.; Hardee, G. E. J. Pharm. Sci., 2008, 97, 225.

11. Davis, S.; Propp, S.; Freier, S. M.; Jones, L. E.; Serra, M. J.; Kinberger, G.; Bhat, B.; Swayze, E. E.; Bennett, C. F.; Esau,C. Nucleic Acids Res., 2009, 37, 70.

12. Nagatsugi, F.; Uemura, K.; Nakashima, S.; Maeda, M.; Sasaki, S. Tetrahedron Lett., 1995, 36, 421.

13. Nagatsugi, F.; Uemura, K.; Nakashima, S.; Maeda, M.; Sasaki, S. Tetrahedron, 1997, 53, 3035.

14. Nagatsugi, F.; Kawasaki, T.; Usui, D.; Maeda, M.; Sasaki, S. J. Am. Chem. Soc., 1999, 121, 6753.

15. Kawasaki, T.; Nagatsugi, F.; Ali, M. M.; Maeda, M.; Sugiyama, K.; Hori, K.; Sasaki, S. J. Org. 
Chem., 2005, 70, 14.

16. Ali, M. M.; Oishi, M.; Nagatsugi, F.; Mori, K.; Nagasaki, Y.; Kataoka, K; Sasaki, S. Angew. Chem. Int. Ed., 2006, 45, 3136.

17. Ali, M. M.; Nagatsugi, F.; Sasaki, S.; Nakahara, R; Maeda, M. Nucleosides, Nucleotides, and Nucleic Acids, 2006, 25, 159.

18. Nagatsugi, F.; Nakahara, R.; Inoue, K; Sasaki, S. Arch. Pharm. Chem. Life Sci., 2008, 341, 562.

19. Ali, M. M.; Imoto, S.; Li, Y.; Sasaki, S.; Nagatsugi, F. Bioorg. Med. Chem., 2009, 17, 2859.

20. Nagatsugi, F.; Sasaki, S.; Miller, P. S; Seidman, M. M. Nucleic Acids Res., 2003, 31, e31.

21. Nagatsugi, F.; Matsuyama, Y.; Maeda, M.; Sasaki, S. Bioorg. Med. Chem. Lett., 2002, 12, 487.

22. Nagatsugi, F.; Usui, D.; Kawasaki, T.; Maeda, M.; Sasaki, S. Bioorg. Med. Chem. Lett., 2001, 11,343 .

23. Grünefeld, P.; Richert, C. J. Org. Chem., 2004, 69, 7543.

24. Adamo, M. F. A.; Adlington, R. M.; Baldwin, J. E.; Day, A. L. Tetrahedron, 2004, 60, 841.

25. Nagatsugi, F.; Ogata, Y.; Imoto, S.; Sasaki, S. Heterocycles, 2007, 73, 493.

26. Fan, F.; Gaffney, B. L.; Jones, R. A. Organic Lett., 2004, 6, 2555.

27. Hattori, K.; Hirohama, T.; Imoto, S.; Kusano, S.; Nagatsugi, F. Chem. Commun. 2009, 6463

28. Y. Pan, A. D. MacKerell Jr, Nucl. Acids Res. 2003, 31, 7131. 
Table 1. The sequences and MALDI-TOF MS results of oligonucleotides (6) containing reactive functional nucleoside derivatives in this study.

\begin{tabular}{|c|c|c|c|}
\hline \multirow[b]{2}{*}{ ODN } & \multirow[b]{2}{*}{ Sequence } & \multicolumn{2}{|c|}{ MALDI-TOF Mass $(\mathrm{m} / \mathrm{z})$} \\
\hline & & calcd. & found. \\
\hline $0-\mathrm{ODN}(\mathbf{8})$ & $5^{\prime}$ d(CTT T(o-AVP_SMe) T TCT CCT TTC T) 3' & 4810.99 & 4809.95 \\
\hline me-ODN(8) & 5' d(CTT T(me-AVP_SMe)T TCT CCT TTC T) 3' & 4825.02 & 4824.39 \\
\hline et-ODN $(\mathbf{8})$ & 5' d(CTT T(et-AVP_SMe) T TCT CCT TTC T) 3' & 4839.05 & 4837.73 \\
\hline bu-ODN(8) & 5' d(CTT T(bu-AVP-SMe)T TCT CCT TTC T) 3' & 4867.11 & 4871.34 \\
\hline $0-O D N(9)$ & 5' d(TAT ACT GAT CAA ATT (0-AVP-SMe) TA T) ${ }^{*} 3^{\prime}$ & 6065.07 & 6071.17 \\
\hline et-ODN(9) & $5^{\prime}$ d(TAT ACT GAT CAA ATT (et-AVP_SMe) TA T) * $3^{\prime}$ & 6093.10 & 6098.34 \\
\hline $\operatorname{ODN}(\mathbf{1 0})$ & $5^{\prime} \mathrm{d}($ TTC GCC TCT TTG ATT AAC GCC) 3' & 6319.98 & 6319.50 \\
\hline $0-O D N(\mathbf{1 0})$ & $5^{\prime} \mathrm{d}(T T C$ GCC TCT TT(O-AVP_SMe) ATT AAC GCC) 3' & 6378.00 & 6381.08 \\
\hline et-ODN(10) & $5^{\prime} \mathrm{d}($ TTC GCC TCT TT(et-AVP_SMe) ATT AAC GCC) 3' & 6406.03 & 6400.53 \\
\hline ODN(11) & $5^{\prime} \mathrm{d}\left(\mathrm{ATG}_{\mathrm{C}} \mathrm{CC} \text { C ATA CTG TTG AGC AAT }\right)^{\star} 3^{\prime}$ & 6611.13 & 6610.10 \\
\hline $0-O D N(11)$ & $5^{\prime} \mathrm{d}\left(\mathrm{ATG}\right.$ CCC ATA CT(0-AVP-SMe) TTG AGC AAT)* $3^{\prime}$ & 6669.15 & 6668.43 \\
\hline et-ODN(11) & $5^{\prime} \mathrm{d}\left(\right.$ ATG CCC ATA CT(et_AVP-SMe) TTG AGC AAT) ${ }^{\star} 3^{\prime}$ & 6691.18 & 6696.54 \\
\hline
\end{tabular}

*These oligonucleotides have an amino linker at the 3 ' end. 
Table 2. $T_{m}$ values of functional nucleosides in ODN with complementary RNA. ${ }^{a}$

\begin{tabular}{lcc}
\hline DNA & Target RNA* & $\left.T_{\mathrm{m}}{ }^{\circ}{ }^{\circ} \mathrm{C}\right)$ \\
\hline ODN(10) & RNA15 & 55.8 \\
o-ODN(10) & RNA15 & 49.4 \\
et-ODN(10) & RNA15 & 50.4 \\
ODN(11) & RNA16 & 64.1 \\
o-ODN(11) & RNA16 & 53.3 \\
et-ODN(11) & RNA16 & 49.7 \\
\hline a UV-melting profiles measured using $1.5 \mu M$ each of the \\
strand in 100 mM NaC1, 50 mM MES buffer, pH 5.0. \\
*RNA15: \\
5' r(CGCUGGGCGUUAAUCAAAGAGGCGAAC) 3' \\
*RNA16: \\
5' r(ACGUGAAUUGUUCAACAGUAUGGGCAU) 3'
\end{tabular}



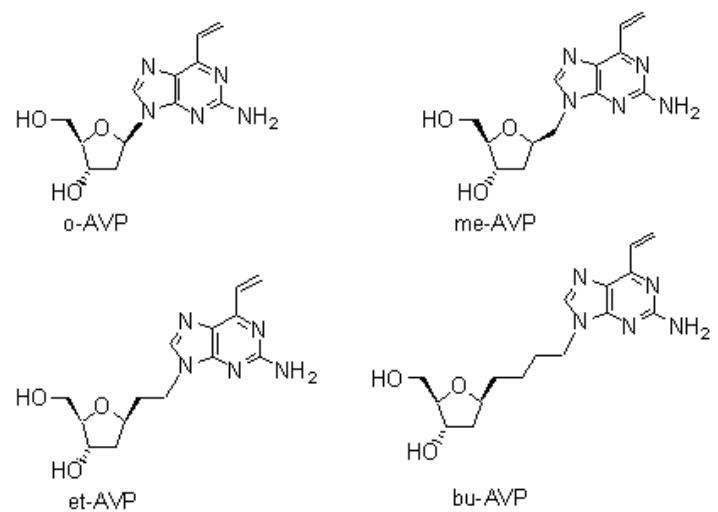

Figure 1. Structures of AVP analogue monomers bearing alkyl linker between $A V P$ and 20f-deoxyribose. 


\section{A: 0-ODN(8)-AVP}

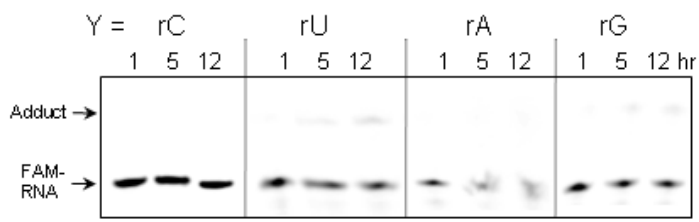

\section{B: et-ODN(8)-AVP}

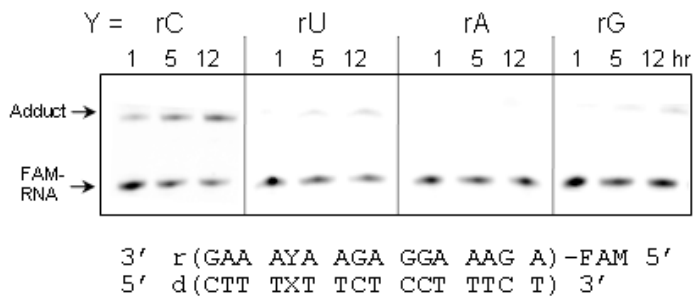

Figure 2. Gel shift assay to determine the cross-linking ability in the reaction buffer containing $100 \mathrm{mM} \mathrm{NaCl}, 50 \mathrm{mM}$ MES pH5.0. (A) o-ODN(8)-AVP and FAM-labeled 16 mer target RNA. (B) et-ODN(8)-AVP and FAM-labeled 16 mer target RNA 
DNA target: DNA12

$3^{\prime}$ d(GAA AYA AGA GGA AAG A) -FAM 5'

A

$5^{\prime}$ d(CTT TXT TCT CCT TTC T) $3^{\prime}$

\section{A}

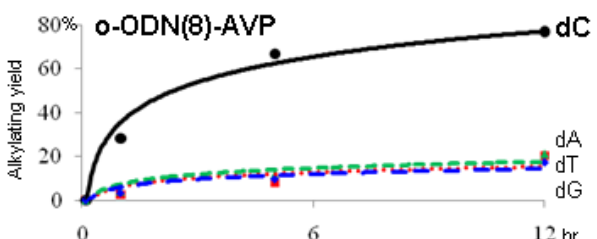

B

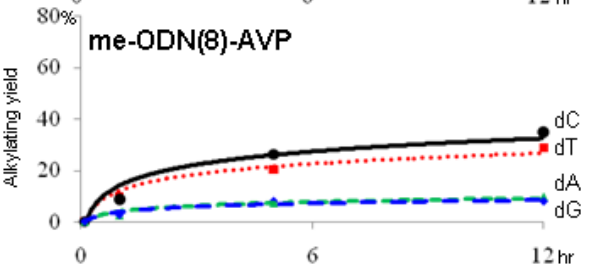

C
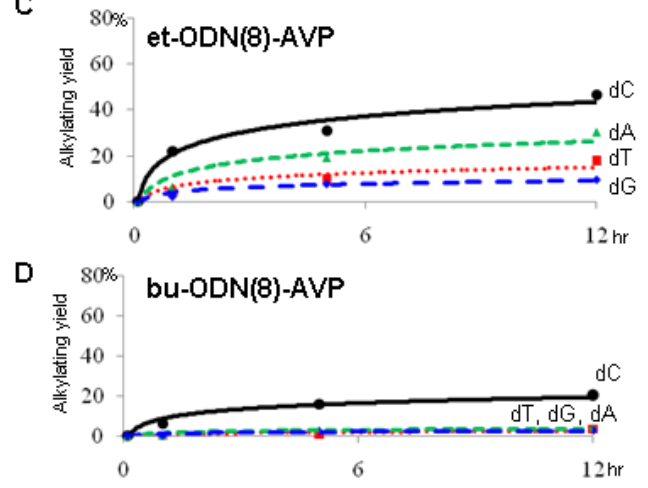

RNA target: RNA13

$$
3^{\prime} \text { r (GAA AYA AGA GGA AAG A) -EAM } 5^{\prime}
$$

E

$5^{\prime} \mathrm{d}\left(\mathrm{CTT}\right.$ TXT TCT CCT TTC T) $3^{\prime}$

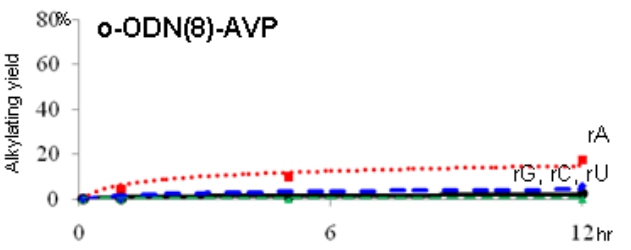

F

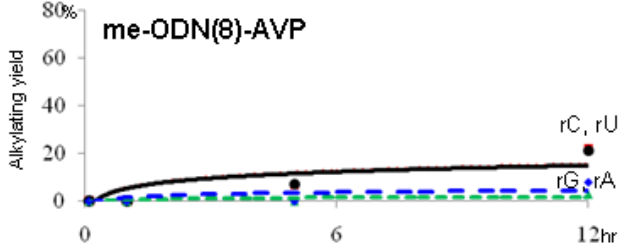

G

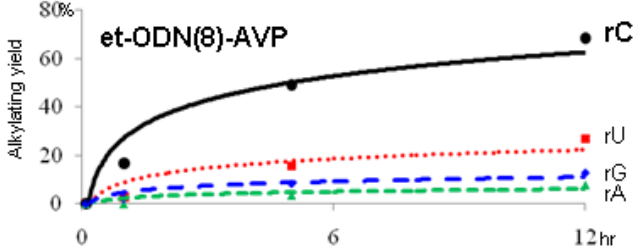

$\mathrm{H}$

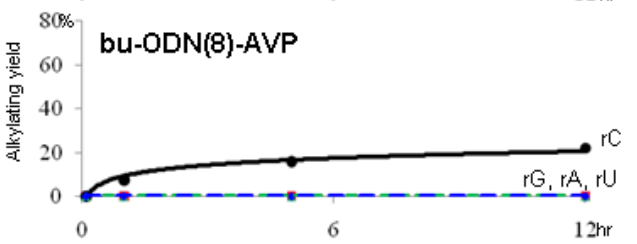

Figure 3. Results of alkylating ability of $10 \mu \mathrm{M} 16$ mer oligonucleotides (o-ODN(8), me-ODN(8), et-ODN(8), bu-ODN(8)) having AVP derivatives for $1 \mu \mathrm{M}$ FAM labeled target DNA (A-D) and target RNA (E-H) (dC and $\mathrm{rC}$ black line, $\mathrm{dT}$ and $\mathrm{rU}$ red line, $\mathrm{dA}$ and $\mathrm{rA}$ green line, $\mathrm{dG}$ and $\mathrm{rG}$ blue line) in the reaction buffer containing $100 \mathrm{mM} \mathrm{NaCl}, 50 \mathrm{mM} \mathrm{MES} \mathrm{pH5.0}$ 

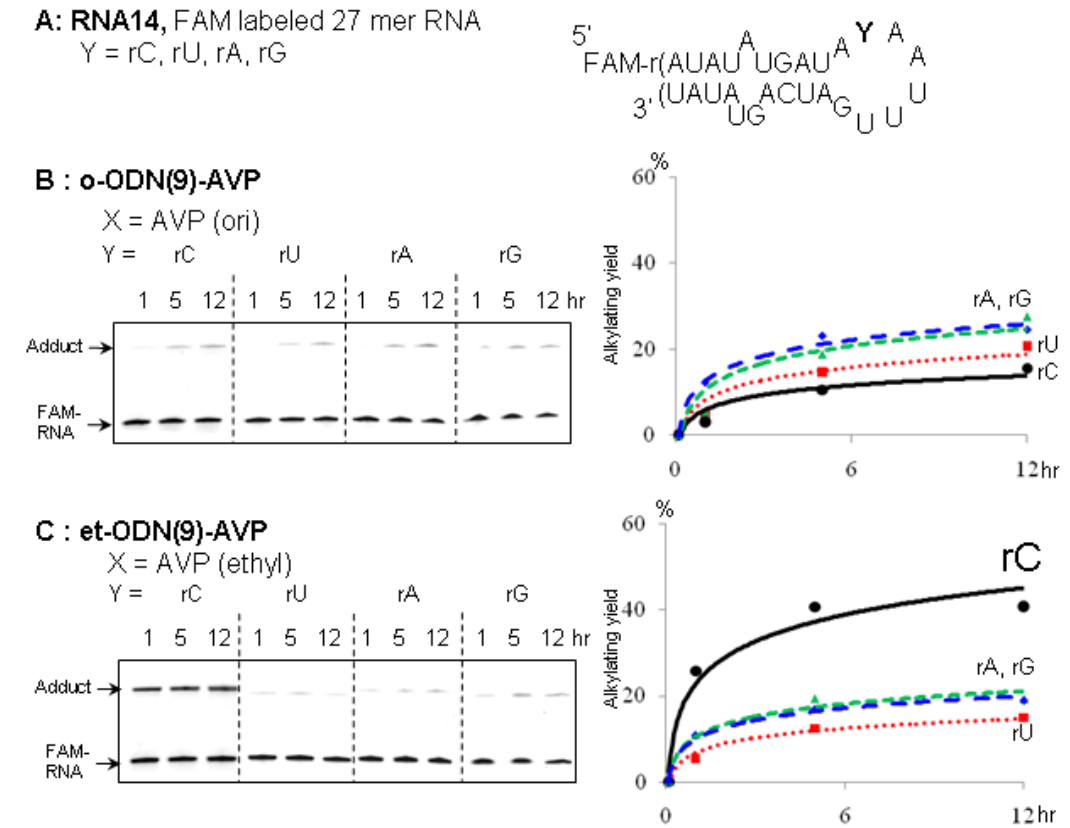

Figure 4. (A) the sequence and the second structure of the target RNA. (B) Gel results and cross-linking yield of the sequence o-ODN(9) containing o-AVP to the target RNA. (C) Gel results and cross-linking yield of the sequence et-ODN(9) containing et-AVP to the target RNA. o- and et-ODN(9) : 5' d(TATACTGATCAAATTXTAT). Conditions: $10 \mu \mathrm{M}$ Reactive ODNs, $1 \mu \mathrm{M}$ FAM-labelled target RNA, $100 \mathrm{mM} \mathrm{NaCl}, 50 \mathrm{mMMES}, \mathrm{pH} 5$ at $37^{\circ} \mathrm{C}$. 
A: FAM-RNA15

$3^{\prime}$ r (CAAGCGGAGA.A.YUA.AUUGCGGGUCGC) -FAM

$5^{\prime} \mathrm{d}\left(\right.$ TTCGCCTCTTTXATTAACGCC) $3^{\prime}$
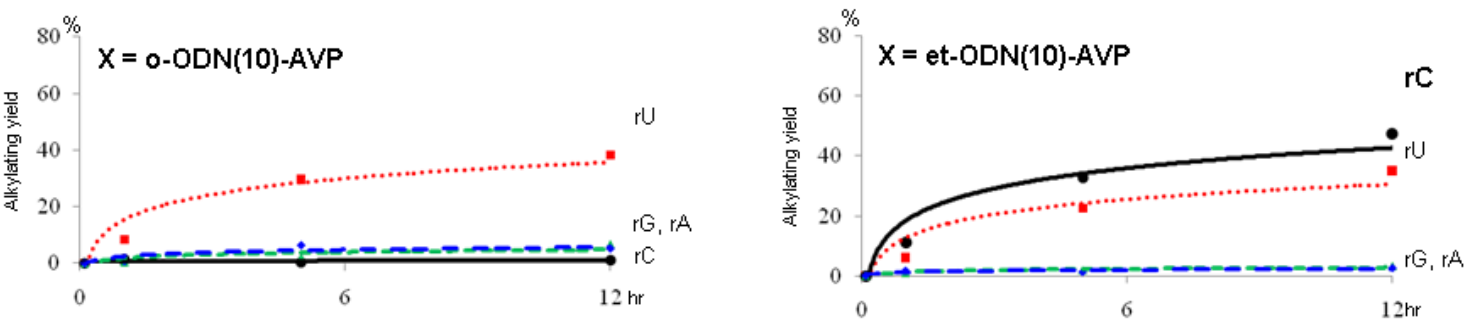

B: FAM-RNA16

$3^{\prime}$ r (UACGGGUAUGAYA.ACUUGUUA.AGUGCA) -E AM

$5^{\prime}$ d(ATGCCCATACTXTTGAGCA.AT) $3^{\prime}$
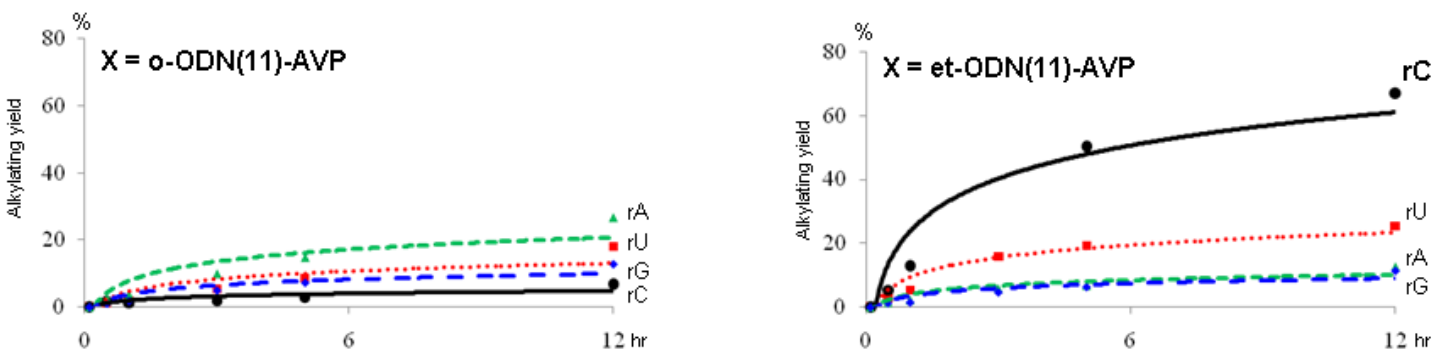

Figure 5. Cross-linking ability for the model sequence of luciferase mRNA. (A) the results of 21 mer 2 'deoxyoligonucleotides o-ODN(10) and et-ODN(10). (B) the results of 21 mer 2'deoxyoligonucleotides o-ODN(11) and et-ODN(11). Conditions: $10 \mu \mathrm{M}$ Reactive ODNs, $1 \mu \mathrm{M}$ FAM-labelled target RNA ( $\mathrm{Y}=\mathrm{rC}, \mathrm{rU}, \mathrm{rA}$ and $\mathrm{rG}$ ), $100 \mathrm{mM} \mathrm{NaCl}$, $50 \mathrm{mMMES}, \mathrm{pH} 5$ at $37^{\circ} \mathrm{C}$. 
A

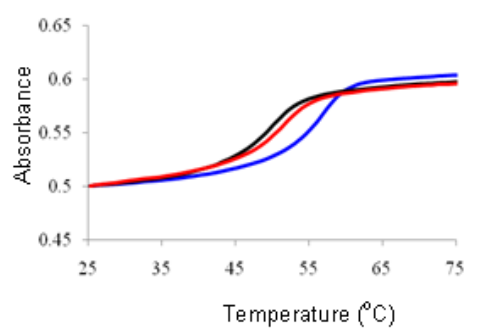

C

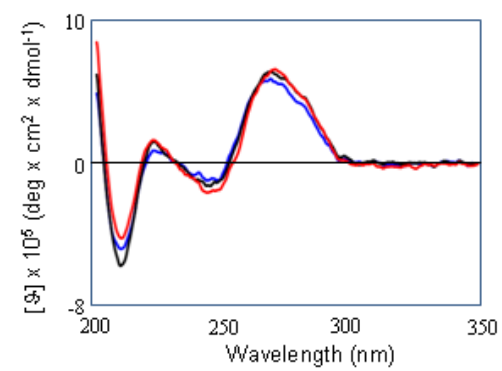

B

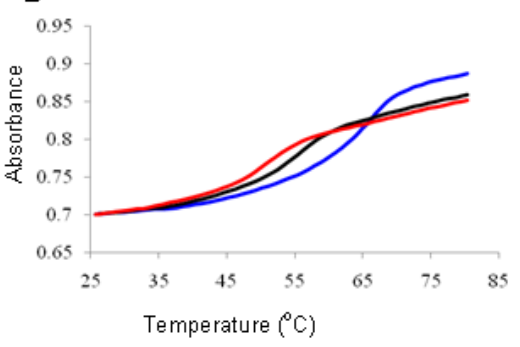

D

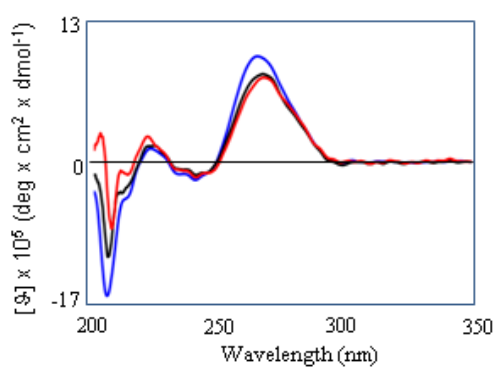

Figure 6. UV-melting curves ( $A$ and $B$ ) and $C D$ spectra $(C$ and $D) . A$ and $C$ show ODN(10)/RNAl5 heteroduplex in blue line, o-ODN(10)/RNAl5 heteroduplex in black line and et-ODN(10)/RNAl5 heteroduplex in red line. B and D show ODN(11)/RNAl6 heteroduplex in blue line, o-ODN(11)/RNAl6 heteroduplex in black line and et-ODN(11)/RNAl6 heteroduplex in red line. The spectra were recorded in $100 \mathrm{mM} \mathrm{NaCl}, 50 \mathrm{mM}$ MES buffer, $\mathrm{pH} 5.0$ at room temperature. The concentration of each strand was 1.5 $\mu \mathrm{M}$. The RNA sequences are described in Table 2. 
A. 1

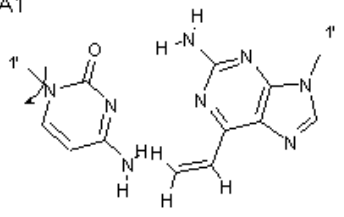

major groove

A2

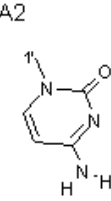

$\mathrm{H}^{\mathrm{H}}$

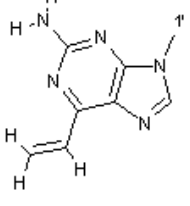

major groove

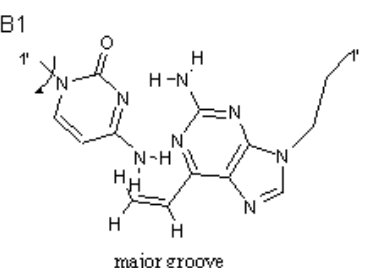

major groove

B2

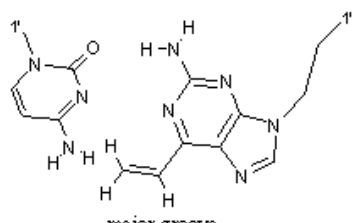

Figure 7. Schematic representations of the 2-amino-6-vinylpurine and the cytosine base (A1 and A2) and the ethylene-linked 2-amino-6vinylpurine and the cytosine base (B1 and $B 2$ ). In $A 1$ and $B 1$, the cytosine base is located at a natural conformation in DNA/RNA duplex (A1 and A2). A2 and B2 illustrate the cytosine base slightly flipped out to the major groove. Only bases are shown for clarity. 


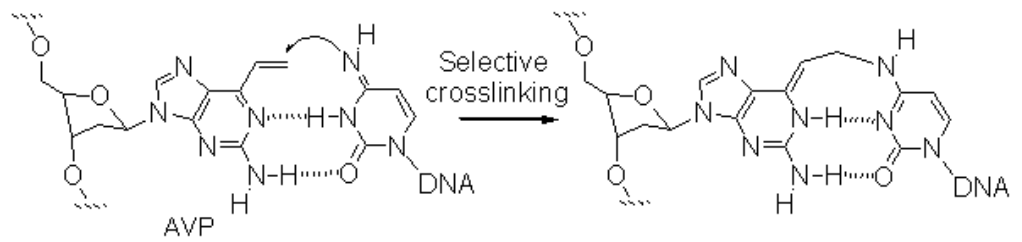

Scheme 1. Predicted alkylation reaction of AVP (2-amino-6-alkyl purine) and cytosine in duplex DNA. 


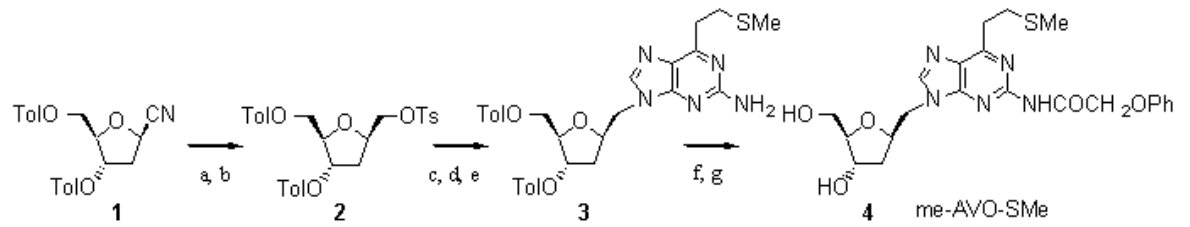

Scheme 2. Reagents and conditions: (a) (1) conc HCl-dioxane, (2) $\mathrm{BH}_{3}-\mathrm{THF}$, dry THF $80 \%$ (2 steps); (b) $p$ - $\mathrm{TsCl}$, dry pyridine $82 \%$; (c) 2-amino-6-chloropurine, $t-\mathrm{BuOK}$, dry DMSO $68 \%$; (d) $\mathrm{Pd}\left(\mathrm{PPh}_{3}\right)_{4}$, Vinylboronic anhydride, $\mathrm{LiBr}, \mathrm{K}_{2} \mathrm{CO}_{3}, \mathrm{H}_{2} \mathrm{O} /$ dioxane; (e) $\mathrm{MeSNa}, \mathrm{CH}_{3} \mathrm{CN} 97 \%$ (2steps); (f) $\mathrm{NaOMe}$, dry $\mathrm{MeOH}$; (g) (1) TMSCl, dry pyridine, dry $\mathrm{CH}_{2} \mathrm{Cl}_{2}$; (2) $\mathrm{PhOAcCl}$; (3) $\mathrm{MeOH}$ $68 \%$ (2 steps); 


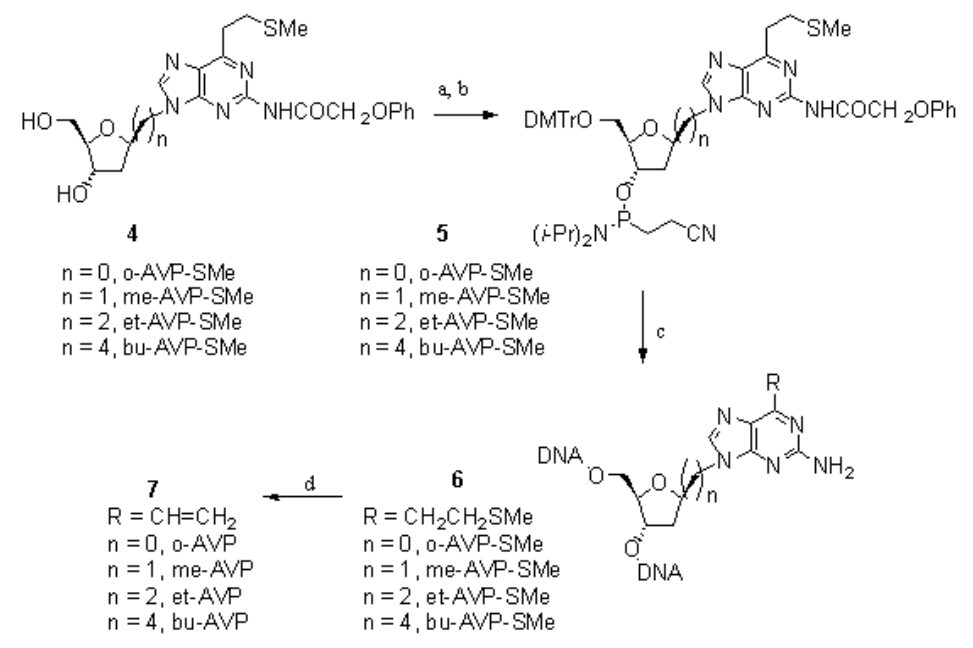

Scheme 3. Reagents and conditions: (a) DMTrCl, pyridine; (b) 2-cyanoethyl- $N, N$-diisopropylchlorophosphoramidite, DIPEA, $\mathrm{CH}_{2} \mathrm{Cl}_{2}$. (c) (1) synthesis with an automated DNA synthesizer, (2) $28 \%$ aqueous $\mathrm{NH}_{3}$, (3) HPLC purification, (4) $10 \%$ $\mathrm{CH}_{3} \mathrm{COOH}$. (d) (1) 2 eq. MMPP, (2) aqueous $\mathrm{NaOH}$. 